\title{
DARBĪBAS VĀRDU İSTENİBAS IZTEIKSMES TAGADNES UN PAGĀTNES DSK. 1. UN 2. PERSONAS GALOTNU -am, -at UN -ahm, -aht LIETOJUMS 17. GS. LATVIEŠU RAKSTU VALODĀ
}

\author{
Jolanta WIŚNIOCH \\ Latvijas Universitātes \\ Baltu valodniecības katedra
}

\section{Ievads}

Mūsdienu latviešu literārajā valodā verbu īstenības izteiksmes pagātnes daudzskaitḷa 1. un 2. personā ir garās galotnes $-\bar{a} m /-\bar{a} t$ pretstatā tagadnes īsajām galotnēm -am / -at (izņemot $\bar{a}$-celma verbus ar galotni -ìt, -ināt nenoteiksmē) (LVG 519). Tomēr rakstu valodas vēsturē tā nav bijis vienmēr. Šai pētījumā uzmanība pievērsta minēto formu lietojumam 17. gadsimta avotos.

R. Grīsle (1959: 509), spriežot par Rēhehūzena gramatiku (1644), rakstīja, ka „starpība starp tagadnes $o$-celmiem un tagadnes, kā arī pagātnes, $\bar{a}$-celmiem daudzskaiț̣a 1. un 2. personas izskaņās nav vērojama - līdzīgi kā citās 17. gs. gramatikās. Bet no tam nav jāsecina, ka šādas starpības nav bijis arī latviešu izrunā. Izskaņas -am, -at vācu autori būs uzskatījuši par nemainīgām personu galotnēm līdzīgi kā vācu -en, -(e)t."

Grīsles secinājums var būt attiecināms arī uz E. Glika Bībeles tulkojuma (1685) materiālu. Analizējot Glika Jaunās Derības četru evaņgêeliju tekstus, konstatēti varianti īstenības izteiksmes daudzskaitḷa 2. pers. galotnes rakstībā - galotne parādās divos variantos -at un -aht. Taču neatkarīgi no verba celma tagadnē tie pamīšus lietoti gan tagadnē, gan pagātnē.

Uz šādu atšķirību galotnes rakstībā norādīja jau P. Šmits (1908: 27) minēdams, ka Glika tulkojumā blakus tagadnes 2. personas daudzskaița galotnei -at reti parādās arī-aht, īpaši Jaunajā Derībā. A. Ozols savā „Veclatviešu rakstu valodā““ (1961: 281) rakstīịis, ka Glika Bībelē verbu tagadnes daudzskaitḷa 2. personas formas indikatīva galotnes -at bieži tiek jauktas ar galotni $-\bar{a} t$.

Nomot vērā E. Lāmes (1933: 104-110) pētījumu par log̣isko rakstību jeb gramatiskās homonīmijas novēršanas principu Glika rakstībā, varētu domāt, ka dažādu galotņu lietojums varbūt ir vēl viens log̣iskās rakstības piemērs. Par tādu var kalpot arī darbības vārdu pagātnes 3. pers. galotṇu $-e$ un $-a$ distribūcija (Wiśnioch 2015: 119-141).

Iespējamie rakstības atšksirīibu iemesli meklēti, veicot Glika Bībeles rakstības iekšējo analīzi un salīdzinot faktus atsevišksās grāmatās. Veikta arī ārējā analīze, salīdzinot Glika rakstību ar citos 17. gs. tekstos izmantoto.

Šajā pētījumā tiek apskatītas indikatīva daudzskaița 1. un 2. personas galotnes -am, -at, resp. -ahm, -aht tagadnē un pagātnē. Salīdzinājumam analizēta arī fonētiski līdzīgu nenoteiksmes formu galotņu rakstība tais pašos avotos. 
Šì pētījuma mērķis ir pārbaudīt, vai:

1) 17. gs. rakstu pieminekḷlos sastopami dažādi 1. un 2. personas galotņu rakstības varianti;

2) 17. gs. rakstībā tiek šķirtas tagadnes un pagātnes formu galotnes;

3) potenciālās atšķirības galotņu lietojumā var būt pamats 17. gs. tekstu dalījumam grupās;

4) ir atšķirības nenoteiksmes formu galotņu rakstībā;

5) Gliks seko citu autoru paraugam vai izstrādā jaunu rakstības sistē$\mathrm{mu}$;

6) - $h$ - var tikt uzskatīts par vokālisma garuma apzīmētāju?

Darbā analizētas darbības vārdu formas no G. Mancẹ̦a Sprediķu grāmatas pirmās dạ̧as (LP1), Glika Jaunās Derības (JD) un pētījuma veikšanas laikā pieejamām Vecās Derības (VD) grāmatām (sk. avotu sarakstu), Kurzemes rokasgrāmatā „Vermehretes Lettif́ches Handbuch“ ievietotajiem K. Fīrekera reliǵiskajiem tekstiem (VLH, VLH Cat, VLH Sal, VLH Syr).

Veikts materiāla salīdzinājums ar H. Ādolfija gramatiku „ErIter Verluch“ (EV), kā arī ar citiem 17. gs. gramatiskajiem darbiem - J. G. Rēhehūzena „Manuductio“(MLL), t. s. Bihnera fragmentiem (A), G. Dresel̨a „Gantz kurtze Anleitung“ (GKA) un J. Langija gramatikas manuskriptu (L).

Visi avoti, izņemot gramatikas, ir pieejami portālā www.korpuss.lv/senie, kur materiāls atlasìts ar meklētāja palīdzību, meklējot formas \%am(ees), \%at(ees) un \%ahm(ees), \%aht(ees).

Visās tabulās tagadnes galotnes ierakstìtas pirmajā vietā parastajā šriftā, turpretī pagātnes galotnes ierakstìtas pēc slīpsvìtras, tās papildus izceḷot ar trekninātiem burtiem.

\section{Darbības vārdu formas 17. gs. gramatikās}

\subsection{Daudzskaitḷa 1. un 2. personas galotnes}

Rēhehūzena gramatikā (1644) tagadnes un pagātnes dsk. 1. un 2. pers. galotnes tiek veidotas pēc model̦a -am, -at - gan tagadnē, gan pagātnē, piem., tag. 1. ludhsam, 2. luhdsat, pag. 1. luhdsam, 2. luhdsat, (MLL 19-20), arī tag. 1. tohpam, 2. tohpat, pag. 1. tappam, 2. tappat (MLL 22). Abu laiku atgriezeniskajās formās arī lietotas vienādas galotnes: $\operatorname{tagadnē~1.~-ameh~} \beta, 2$. -ateh $\beta$ / -atheß (MLL 24), pagātnē 1. -amehß 2. -atehß (MLL 24-25).

T. s. Bihnera gramatikas (ap 1667-1677) apskatā tagadnes un pagātnes dsk. 1. un 2. pers. galotnes ir šādas: tag. 1. -am, 2. -aht, pag. 1, -am, 2. -aht, piem., 1. Eijam, eetam, 2. Ejaht, eetaht; gahjam, gajaht (A 269; arī 272). Rakstība ar - $h$ - dsk. 2. pers. izskaņā tiek atkārtota arī kondicionāḷa galotnēs: 
1. -atam / -atubam, 2. -ataht / -atubaht (A 272), tomēr neparādās atgriezeniskā formanta priekšā: 1. -amees, 2. -atees (A 270) abos laikos.

Līdzīgi kā Bihnera darbā, G. Dreseḷa gramatikā (1685) divu un vairāku zilbju verbiem ar -aht, -eht, -iht, -oht, -uht nenoteiksmes izskaņā abos laikos lietotas attiecīgi galotnes: 1. -am, 2. -aht, tagadnē piem., mehs runnajam (alii runnam), juhs runnaht un pagātnē: mehs runnayjam, juhs runnayjaht (GKA 18). Tās tiek atkārtotas arī kondicionālī: 1. śarrgahtam / śarrgahtubam, 2. śarrgahtaht / śarrgahtubaht (GKA 23-24). Tāpat tiek veidotas verba būt formas: 1. byjam, 2. byjaht (GKA 21). Verbiem ar līdzskani pirms infinitīva galotnes - $t$ dsk. 1. un 2. pers. formas nav sniegtas, bet verba tapt paradigmā parādās vairāki galotņu varianti - tag.: 1. tohpam, 2. tohpat (GKA 26) / tohpaht (GKA 60); pag.: 1. tappam, 2. tappat (GKA 27) / tappaht (GKA 60). Formas ar -h- dsk. 2. pers. galotnes izskaņā abos laikos ir pārsvarā. Atgriezeniskā formanta priekšā abos laikos izmantotas galotnes bez - $h$-: 1. -(aj)amees, 2. -(aj) atees (GKA 64-65).

Vispilnīgākais darbības vārdu formu teorētiskais apraksts sniegts H. Ādolfija gramatikā (1685). Viņš raksta: „Secunda perfona pluralis Præentis Indicativi, Imperativi \& Conjunctivi hat offe wol dreyerley Endungen. Alß/ajt/ aht/eet. Alß: juhs darrajt/darraht/darreet. Aber doch nicht allezeit/ noch in allen Verbis." (EV 59) Tomēr paradigmās rakstība ar - $h$ - parādās tikai verba sargāt formās: tag. 1. śargam, 2. śargaht; pag. 1. śargajam, 2. śargajaht (EV 66). Pārējiem Ādolfija 1. konjugācijas verbiem konsekventi abos laikos lietotas galotnes: 1. -am, 2. -at (tagadnē reti arī-eet), piem., tag. 1. darram, 2. darrat; pag. 1. darrijam, 2. darrijat (EV 90). Līdzīgi arī Ādolfija 2. un 3. konjugācijas verbiem (vienzilbīgie verbi ar patskani resp. līdzskani -t priekšā), piem., 1. dohdam, 2. dohdat (EV 131); 1. weddam, 2. weddat (EV 206). Vienīgais izņēmums ir verba gérerbt tagadnes dsk. 2. forma gehrbjaht blakus pag. formai gehrbat /-et (EV 147).

Atgriezeniskā formanta priekšā visiem verbiem 1. un 2. pers. galotnes abos laikos rakstītas bez - $h$-: 1. -(aj)amees, 2 -(aj)atees (EV 77), piem., śargamees, śargatees (EV 77), redfamees, redfatees (EV 87), darramees, darratees (EV 92), barrrojamees, barrrojatees (EV 95).

Attiecībā uz savas 3. konjugācijas verbu pagātnes galotnēm Ādolfijs norāda, ka „Herr Fürreccerus das Imperfectum Indicativi, welches fich in den anderen beyden Conjugationibus, wie auch in den meiften Verbis diefer dritten Conjugation, in Plurali auff ein am/at/e/ endet; in vielen Verbis diefer Conjugation auff ein em/ et/e/ formire. Kan aber die Urfache / wie fleißig ich darnach gefuchet / nicht finden / noch von andern / wie fleißig ich darnach geforfchet / davon belehret werden: Habe demnach nach beyden Endungen in denenfelben Verbis die Imperfecta Pluralia gefetzet / und laffe denen / die deffen Grund wiffen / ihre freye Wahl." (EV 135) Gramatikā vairākiem verbiem dsk. 1. un 2. pers. atrodami abi galotņu varianti, 
piem., 1. breedam / breedem, 2. breedat / breedet (EV 141). Visos gadījumos galotnes rakstītas bez $-h-$.

Langija vārdnīcas manuskripta (1685) gramatiskajā pielikumā sniegtajos piemēros abos laikos redzamas galotnes: 1. -am (i-celmiem arī -im), 2. -at, piem., tagadnē 1. eetam, 2. eiat, pagātnē 1. gahjam, 2. gahjat (L 198a). Gramatika nesniedz skaidru atbildi par atgriezenisko verbu galotnēm. Tekstā atrodama vienīgi tagadnes dsk. 1. pers. forma: turrimees (L 208a), kas raksturīga $i$-celma verbiem un rakstìta bez $-h-$.

\subsection{Nenoteiksmes formas}

Rēhehūzena gramatikā visās sekundāro verbu nenoteiksmes formās galotnes -t priekšă ir apzīmēts patskaņa garums, piem., runnaht (MLL 13), redfäht (MLL 13), maldiht (MLL 32), Sztaigkaht (MLL 34). Arī vien̄igā sekundārā atgriezeniskā verba nenoteiksmē patskanim seko - $h$-: turrähteh $\boldsymbol{\beta}$ (MLL 24).

Arī Bihnera piezīmēs sekundāro verbu nenoteiksmē parasti lietots $-h$ - galotnes -t priekšā, piem., śargaht (A 272), glabbaht, lammaht, raudaht (A 273), bet vien̄igā atgriezeniskā verba nenoteiksme rakstīta bez - $h$-: śargatEES (A 270).

Tāda pati sistēma redzama Dreseḷa gramatikā. Visu sekundāro verbu nenoteiksmes formās atrodams patskaņa garuma apzīmējums, piem., śinnaht, Śarrgaht, runnaht (GKA 16), daufiht '(GKA 40), ghuhftiet (GKA 42). Vienīgā atgriezeniskā verba infinitīvs rakstīts bez garuma apzīmējuma: Preezatees (GKA 66).

Arī Ādolfija gramatikā visiem viņa 1. konjugācijas jeb vairākzilbīgajiem verbiem nenoteiksmes formās regulāri lietota galotne ar - $h-$, piem., śargaht (EV 57), redfeht (EV 57), barroht (EV 57), darriht (EV 91); dabbuht (EV 98). Savukārt atbilstošie atgriezeniskie verbi konsekventi rakstīti bez - $h$-, piem., Śargatees, Maitatees (EV 75), Apzerretees, Brihnotees (EV 76), Darritees (EV 93).

Vairāk variāciju redzams Langija vārdnīcas gramatiskajā pielikumā. Tajā sekundāro tiešo verbu infinitīvi arī lielākoties rakstīti, atzīmējot patskaņa garumu formanta -t priekšā, piem., Maxaht (L 184a), Runnaht (L 188), Staiǵaht (L 210), darriht (L 185), Karŗoht (L 197a), Dfirdäht (L 204), bet arī maxat (L 208a) - bez $-h-$. Atgriezenisko verbu nenoteiksmes formas rakstītas gan ar, gan bez - $h$-, piem., Turrähtees (L 208), śohdihtees (L 208a), bet Laizitees (L 185), Criftitees (L 208a).

\subsection{Kopsavilkums}

Tādējādi 17. gs. gramatiskajos darbos ir redzama skaidra aplūkojamo verba formu sistēma:

- tiešo darbības vārdu dsk. 1. pers. galotne visos gadījumos rakstīta -am;

- atgriezenisko darbības vārdu dsk. 1. un 2. pers. galotnes ir attiecīgi -amees un -atees; 
- tiešo darbības vārdu dsk. 2. pers. formu galotnēs iespējami 2 rakstības varianti - ar un bez $-h-$;

- Bihnera un Dreseḷa gramatikās dsk. 2. pers. lietota galotne -aht;

- Rēhehūzena un Langija gramatikās lietota vien̄igi galotne -at;

- Ādolfija gramatikā galotne -aht reǵistrēta 1 verbam, visiem pārējiem lietota galotne -at;

- katrā no darbiem izvēelētais rakstības variants unificēts par kopīgo dsk. 2. pers. galotni gan tagadnē, gan pagātnē;

- nenoteiksmes formanta $-t$ priekšā visās gramatikās tiešo verbu formas rakstītas ar garuma apzīmējumu - $h$ - (vai -ie-), bet atgriezenisko verbu formas - bez tā. Svārstības parādās tikai Langija gramatikā.

\section{Daudzskaitḷa 1. personas galotnes 17. gs. religigiskajos rakstos}

\subsection{G. Manceḷa „Lang=gewünschte Lettische Postill“ 1. daḷa (1654)}

Mancelis savas Sprediķu grāmatas pirmajā daḷā dsk. 1. pers. formās lieto gandrīz vien̄̄gi galotni -am. Tā ir reǵistrēta 713 gadījumos tagadnē, piem., fchkeetam (2), dfärrram (1), jämmam (4), un 17 reizes pagātnē, piem., bijam (7), dabbujam (1), śehdejam (1). Vienīgais izñēmums ir tagadnes forma zeenahm teikumā: To Draudfibu to Śwähto ze en a h m und mieļojam mehß / (LP1 204, 15). Galotne -am lietota arī reg̣istrētajās atgriezeniskajās formās, attiecīgi 31 gadījumā tagadnē, piem., dohdameeß (1), śchaubameeß (2), un 1 reizi pagātnē: eе $=$ preezajamee $\boldsymbol{\beta}(\mathrm{LP} 1309,8)$.

\subsection{K. Fīrekera reliǵiskie raksti (1685)}

Vien̄̄gi formas bez - $h$ - reg̣istrētas arī aplūkotajos Fīrekera reliğiskajos darbos. Galotne -am 164 reizes lietota tagadnē, piem., eśśam (7 - VLH), prohtam (1 - VLH Sal), dfirfcham (1 - VLH Syr), bet 10 gadījumos pagātnē, piem., bijam (3 - VLH), eenihdejam (1 - VLH), redfejam (1 - VLH). Bez - $h$ - rakstìtas arī 10 reǵistrētās atgriezenisko verbu tagadnes formas, piem., apfkaitamees (1 - VLH), palıujamees (1 - VLH), brihnojamees (1 - VLH Syr).

\subsection{E. Glika Bībeles tulkojums (1685-1694)}

Arī Glika Jaunajā Derībā (1685) tagadnes un pagātnes dsk. 1. pers. formās lietota galotne -am. Tā reg̣istrēta 694 atlasìtajām dsk. 1. pers. formām kā tagadnē (628 reizes), tā pagātnē (66 reizes), piem., warram (20) / warrejam (5).

Galotne -am lietota arī Vecajā Derībā (1689), kur tā reǵistrēta 611 reizes - 525 gadījumos tagadnē, piem., dferŗam (3), isnihk/tam (1), kā arī 86 gadījumos - pagātnē, piem., palikkam (2), redfejam (3). 
-am(ees) ir vienīgā iespējamā atgriezenisko verbu dsk. 1. pers. galotne. Bībelē tā kopumā reǵistrēta 79 gadījumos: 63 reizes tagadnē, piem., bihftamees ( 1 - JT), djennamees $(1$ - JT), kaujamees $(2$ - VD), un 16 - pagātnē, piem., nozehlamees $(5-\mathrm{JT})$, atgree amees $(1-\mathrm{VD})$, turrejamees $(2$ - VD), tostarp 1 reizi evaņgēelijos: Kungs/ mehs a tgahdaja mees / ka śchis Wiltneeks wehl dfihws buhdams śazzija: pehz trim Deenahm gribbu es augścham zeltees (JT Mt 27:63).

\subsection{Kopsavilkums}

Kopumā apskatītais materiāls parāda, ka variants ar -am(-):

- $\quad$ ir vienīgais iespējamais tiešo darbības vārdu tagadnes un pagātnes dsk. 1. pers. galotnēs;

- $\quad$ ir arī vienīgais lietotais atgriezenisko verbu dsk. 1. pers. formās.

Nevienā no avotiem nav lietota potenciāli iespējama atgriezenisko verbu tagadnes un pagātnes dsk. 1. pers. forma ar $-h$-galotnē ( ${ }^{\circ}$-ahmees).

1. tabula

Daudzskaitḷa 1. personas galotnes 17. gs. religigiskajos rakstos

\begin{tabular}{|c|c|c|c|c|c|c|c|c|c|}
\hline & \multicolumn{5}{|c|}{ JD } & \multirow[t]{2}{*}{ VD } & \multirow[t]{2}{*}{ VLH } & \multirow[t]{2}{*}{ LP1 } & \multirow[b]{2}{*}{ kopā } \\
\hline & Mt & Mk & Lk & In & \begin{tabular}{|c|} 
citas JD \\
grāmatas
\end{tabular} & & & & \\
\hline$-a m$ & $26 / 1$ & $\mid 16 / 2$ & $17 / 2$ & $49 / 1$ & $520 / 61$ & $525 / 86$ & $164 / 9$ & \begin{tabular}{|l|}
$703 / 17$ \\
\end{tabular} & $2020 / 179$ \\
\hline$-a h m$ & - & - & - & - & - & - & - & $1 /-$ & $1 /-$ \\
\hline -amees & $-/ 1$ & - & - & - & $35 / 8$ & $28 / 7$ & 10 & $31 / 1$ & $104 / 17$ \\
\hline kopā & $26 / 2$ & $16 / 2$ & $17 / 2$ & $49 / 1$ & $555 / 69$ & $553 / 93$ & $174 / 9$ & $735 / 18$ & $2125 / 196$ \\
\hline
\end{tabular}

\section{Daudzskaiț̣a 2. personas galotnes 17. gs. reliğiskajos darbos}

\subsection{G. Mancel̦a „Lang=gewünfchte Lettifche Poftill“ 1 . daḷa (1654)}

Manceḷa Sprediķu grāmatas pirmajā dạ̧ā verbu dsk. 2. pers. galotnē lietotas tikai formas ar $-h$ - galotnē -112 reizes. No tām - 106 gadījumos tagadnē, piem., finnaht (16), dfirrdaht (11), palleekaht (1), un 6 - pagātnē, piem., bijaht (1), ghribbejaht (1), kluaht (1).

Tekstā reǵistrētas 5 atgriezenisko verbu tagadnes dsk. 2. pers. formas, kas visos gadījumos rakstītas bez - $h$ - galotnē, piem., fchkeetatee $\boldsymbol{\beta}$ (1), leedfateeß (1).

\subsection{K. Fīrekera relig̣iskie raksti (1685)}

Fīrekera perikopēs un citos religíska satura darbos (VLH, VLH Cat, VLH Sal, VLH Syr) lietotās dsk. 2. pers. tagadnes un pagātnes formas iespējams 
salīdzināt ar Fīrekera materiālos balstītās Ādolfija gramatikas (EV) datiem. Neskatoties uz faktu, ka tekstu pamatā ir viena autora darbi un tie izdoti tajā pašā gadā, galotņu rakstībā konstatētas fundamentālas atšksirības.

Fīrekera perikopju tulkojumos (VLH) lietota vienīgi galotne -aht. Tā parādās 100 tagadnes formās, piem., finnaht (14), gaidaht (1), dabbujaht (2), apśmeijaht (1), kā arī visās 9 tekstā reǵistrētajās pagātnes formās, piem., bijaht (4), tappaht (1).

Pārēiās analizētajās Kurzemes rokasgrāmatas daḷās - Zālamana pamācībās (VLH Sal), Zīraka gudrības grāmatā (VLH Syr), kā arī Mazajā Katehismā (VLH Cat) - izmantotā rakstība nesniedz viennozīmīgu atbildi par galotņu lietojumu. Sal reg̣istrēta tikai viena tagadnes forma ar galotni -at: ka juhs mahzajtees/ in Gudri tohpat (VLH Sal 5B, 19). Cat tekstā 2 reizes parādās tag. dsk. 2. pers. forma ar galotni -aht: atfihftaht (1), dohmajaht (1).

Lìdzīgi kā iepriekš, pirms atgriezeniskā formanta tagadnes dsk. 2. pers. formās lietota galotne bez $-h$-. Kopumā reǵistrētas 3 šādas formas: gribbatees, kaunajatees, leed/atees.

Turpretim 1685. g. gramatikā gandrīz visās tagadnes dsk. 2. pers. formās lietota galotne bez - $h-$, reti tā parādās paralēli ar galotni -eet, piem., dabuhjeet (EV 97), krahjeet (EV 101). Dsk. 2. pers. galotne -at tiek atkārtota arī pagātnē tā lietota attiecīgi 224 un 231 gadījumos, piem., darrat (EV 90) un darrijat (EV 90). Tā vienmēer parādās palīgverbiem būt un tapt abos laikos. Avotā konstatēti tikai 4 piemēri ar - $h$ - formas izskaņā. Gan tagadnē, gan pagātnē tas konstatēts tikai verbam sargāt indikatīvā: juhs sargaht, sargajaht (EV 66). Konjunktīvā forma lietota bez - $h$-: juhs sargat. Verbiem diet un gér $b t$ tagadnē ir galotne -aht, bet pagātnē -at (EV 114 un 147).

Visos Fīrekera avotos atgriezenisko verbu formās lietota vienīgi galotne -atees gan tagadnē, gan pagātnē. Ādolfijs sniedz refleksīvo verbu piemērus tikai 1. un 2. konjugācijas verbiem. 1. konjugācijā (daudzzilbīgie verbi ar-aht, -eht, -iht, -uht izskaņā), piem., śargatees (EV 77), redfatees (EV 87), darratees (EV 92), barrrojatees (EV 95) un dabujatees (EV 99). 2. konjugācijā (vienzilbīgie verbi ar -aht, -eht, -iht), piem., kaujatees (EV 107), śmeijatees (EV 112), śeenatees (EV 117).

2. tabula

Daudzskaitḷa 2. personas galotnes K. Fīrekera darbos

\begin{tabular}{|l|c|c|c|c|c|c|}
\hline & VLH & VLH Cat & VLH Sal & VLH Syr & EV & kopā \\
\hline -at & - & - & $1 /-$ & - & $224 / \mathbf{2 3 1}$ & $226 / \mathbf{2 3 1}$ \\
\hline -aht & $100 / \mathbf{9}$ & $2 /-$ & - & - & 4 & $106 / \mathbf{9}$ \\
\hline -atees & $4 /-$ & $1 /-$ & $1 /-$ & $1 /-$ & $9 / \mathbf{4}$ & $16 / \mathbf{4}$ \\
\hline kopā & $104 / \mathbf{9}$ & 3 & 2 & 2 & $237 / \mathbf{2 3 5}$ & $348 / \mathbf{2 4 4}$ \\
\hline
\end{tabular}


Kopumā Fīrekera tekstos redzamas atšķirības dsk. 2. pers. galotnes rakstībā:

- gramatikā abos laikos regulāri lietota galotne -at;

- reliğiskajos darbos gandrīz vienīgi galotne -aht;

- visos tekstos refleksivvo verbu galotne ir -atees.

Šādas atšksirības varētu būt radušās Ādolfija redakcionālā darba rezultātā. Kā raksta R. Grabis (1955: 229) - gramatika ir „uz Fīrekera gramatiskiem atzinumiem par latviešu valodu balstīts Adolfija darbs“. Ādolfija aktīva iejaukšanās tekstā ir fiksēta ar jau minētājām pagātnes daudzskaitḷa 1. un 2. personas galotnēm -em, -et (skat. 2.1.). To, ka arī citu verbu galotņu rakstībā ir redzama Ādolfija „roka“, ḷauj secināt salīdzinājums ar tajā pašā gadā izdoto Dreseḷa gramatiku „Gantz kurtze Anleitung zur Lettifchen Sprache“. Arī šì darba priekšvārdā atrodama autora norāde, ka viņš balstīijies uz Fīrekera materiāla. Tomēr Dreselim tiešo verbu dsk. 2. pers. galotnes ir citādas - viņa darbā galotne -aht ir pārsvarā kā tagadnē, piem., äsśaht (GKA 57), runnaht (GKA 18), jahjaht (GKA 33), bḷauhjaht (GKA 34), tā arī pagātnē, piem., byjaht 5 (piem., GKA 21), runnajaht (GKA 18), śehjaht (GKA 36).

\subsection{E. Glika Bībeles tulkojums (1685-1694)}

No ievadā minētajām Bībeles tulkojuma grāmatām kopumā ekscerpētas 1633 tiešo verbu dsk. 2. pers. formas ar galotni -at. No tām lielāko daḷu 1539 - veido dsk. 2. pers. tagadnes formas, bet 94 - pagātnes formas. Vienlaikus apskatītajos tekstos reǵistrētas arī 267 dsk. 2. pers. formas ar galotni -aht. No tām 260 ir tagadnes, bet 7 - pagātnes formas.

Reg̣istrētas arī 88 atgriezenisko verbu dsk. 2. pers. formas, kas visos gadījumos lietotas ar galotni -atees. 82 no tām ir tagadnes, bet 6 - pagātnes formas. Nevienā no aplūkotajām Bībeles grāmatām nav konstatētas atgriezenisko verbu daudzskaiţ̦a 2. pers. formas ar -aht- pirms atgriezeniskā formanta.

Jaunajā Derībā reǵistrētas 770 dsk. 2. pers. galotnes ar rakstījumu -at un 256 ar -aht. Vecajā Derībā reg̣istrētas vienīgi 967 formas ar -at. Izteiktākas atšķirības abu galotņu lietojumā redzamas JD četru evaņgéeliju tulkojumā.

Mateja un Marka evaņgêelijos tiešajiem verbiem abos laikos lietota vien̄̄gi galotne ar - $h$ - izskaņā.

Mt tā parādās attiecīgi 138 tagadnes formās, piem., eśśaht (42), dfirdaht (2), warraht (4), atrohdaht (1). Tā reǵistrēta arī 5 pagātnes formās, piem., gribbejaht (4), redfejaht (1): Jeb ko eśśaht juhs isgahjuśchi fkattitees? (g ribbeja ht juhs) kahdu Zilweku mihkftâs Drehbês (redfeht?) (JT Mt 11:8).

Mk tulkojumā reǵistrētas vien̄igi tagadnes formas, visos 62 gadījumos tās lietotas ar galotni -aht, piem., peederraht (1), mehriojaht (1), peedohdaht (1).

Lūkas un Jāņa evaņgéelijos ir atšķirīgss verbu galotņu lietojums. 
3. tabula

Daudzskaitḷa 2. personas galotnes Bībelē

\begin{tabular}{|c|c|c|c|c|c|c|c|}
\hline & \multicolumn{5}{|c|}{ JD } & \multirow[t]{2}{*}{ VD } & \multirow[t]{2}{*}{ kopā } \\
\hline & Mt & Mk & Lk & Iṇ & $\begin{array}{c}\text { citas JD } \\
\text { grāmatas }\end{array}$ & & \\
\hline$-a t$ & - & - & 53 & 133 & $524 / 20$ & $829 / 74$ & $1539 / 94$ \\
\hline -aht & $138 / 5$ & 62 & $53 / 1$ & $3 / 1$ & - & $4 /-$ & $260 / 7$ \\
\hline -atees & 3 & - & 1 & 4 & 20 & $54 / 6$ & $82 / 6$ \\
\hline kopā & $141 / 5$ & 62 & $107 / \mathbf{1}$ & $140 / 1$ & $544 / 20$ & $887 / 80$ & $1881 / 107$ \\
\hline
\end{tabular}

Lk abu galotnes variantu skaits tagadnē ir vienāds - 53 formas ar -at un 53 ar-aht, piem., eśśat (26) un eśśaht (10), śchķeetaht (1), dohmajaht (2); meklejat (1), kahrdinajat (1). Tekstā reg̣istrēta viena pagātnes forma - tā rakstīta ar -h- galotnē: finnajaht.

Iñ 133 ekscerpētajās tagadnes formās regulāri lietota galotne -at, piem., eśśat (32), mihlojat (2), peeminnat (1), darrat (5). Nav reǵistrētas pagātnes formas ar šo galotni. Tekstā konstatēti arī 4 gadījumi ar galotni -aht - 3 tagadnē: meklejaht, pafihftaht (J̧̣ 1), eśśaht (J̧̣ 5), kā arī 1 pagātnē: gribbejaht (Jņ 5).

Citās Jaunās Derības grāmatās reg̣istrētas 542 darbības vārdu dsk. 2. pers. formas ar galotni -at: 524 lietotas tagadnē, piem., prohtat (1), raugat (1), red/at (8), bet 20 - pagātnē, piem., bijat (15), tappat (2).

Līdzīgi arī aplūkotajās Vecās Derības grāmatās. Te galotne -at lietota 903 gadījumos: 829 - tagadnes formās, piem., finnat (13), fpahrdat (1), aiskarr,at (1), bet 74 - pagātnē, piem., klauśijat (3), lakftijat (1), nahzat (5). Galotne -aht parādās tikai 4 tagadnes formās: finnaht (VD 1Ķēn 22:3), apśmeijaht (VD Soğ 19:24), eenihdaht (VD 1Moz 26:27), isdeldaht (VD Ech 9:6), piem., ka juhs tahs a pśmeijaht / un tahm darrat / kas jums patihk/ (VD Soǵ 19:24).

Visā Bībelē reǵistrētas 88 atgriezenisko verbu dsk. 2. pers. formas - visās galotne rakstìta bez - $h$-. 82 no tām lietotas tagadnē, piem., fudatees (1), pahrwehrśchatees (1), śchaubatees (1), śmejatees (1), bet 6 - pagātnē, piem., atgreejatees (1), bihjajatees (1), leedfatees (1). Visas šīs formas ekscerpētas no Vecās Derības.

Bībelē atrasto formu analīze parāda šādas iezīmes:

- Bībelē kopumā lielākoties lietotas dsk. 2. pers. galotnes bez - $h$-:

- bez - $h$ rakstìta lielākā daḷa tagadnes un gandrīz visas pagātnes formas;

- atgriezeniskajiem darbības vārdiem abos laikos lietota galotne -atees.

- Dažāda rakstība lietota evaņgéēliju tekstos tiešo verbu formās:

- Mt, Mk lietota vienīgi galotne -aht; 
- Lk galotņu -at un -aht skaits ir gandrīz identisks - 53/54;

- Jñ gandrīz vienmēr lietota galotne -at.

- Iñ lietotā sistēma ievērota arī pārējās JD, kā arī VD grāmatās.

- Attiecīgajā grāmatā valdošais variants lietots gan tagadnes, gan pagātnes formās.

\subsection{Kopsavilkums}

17. gs. rakstu pieminekḷos atrasto verbu dsk. 2. pers. galoţ̦u analīze parāda, ka autoriem bijusi tendence vienā avotā izvēēêties vienu konkrētu galotnes rakstības variantu, kas lietots gan tagadnē, gan pagātnē:

1) Manceļa sprediķu grāmatā lietota galotne -aht;

2) Fīrekera darbos:

a) gramatikā lietota galotne -aht;

b) reliǵiskajos tekstos Kurzemes rokasgrāmatā - galotne -at;

3) Glika Bībeles tulkojumā lietoti abi galotņu varianti.

Visos avotos refleksīvo verbu galotne tagadnē un pagātnē ir -atees.

\section{Nenoteiksmes galotnes}

\subsection{G. Manceḷa „Lang=gewünfchte Lettifche Poftill“ 1 . daḷa (1654)}

Manceḷa Sprediḳu grāmatas 1. dạ̧ā tiešajiem darbības vārdiem ar garu patskani vai divskani /uo/ nenoteiksmes formanta $-t$ priekšā šai formā pārsvarā lietota rakstība ar -h-, kopumā 1267 piemēri. Tikai 6 gadījumos - $h-$ netiek lietots, sal. -aht (436) un -at (5); - eht (559) un -et (1); -oht (272), piem., finnaht (50), ftaighaht (11), bet apdohmat (2), pafśarghat (1). Analīzē nav ņemti vērā 815 gadījumi ar izskaņu -īt, kurā vienmēr patskanis $/ \overline{1} /$ rakstīts ar -ie-.

Atgriezenisko darbības vārdu nenoteiksmē pirms atgriezeniskā formanta lietota galvenokārt rakstība bez - $h$-: -еtee $\beta$ (47); -atee $\beta$ (47); -otee $\beta(24)$, piem., aprunnatee $\boldsymbol{\beta}$ (1), attghadatee $\boldsymbol{\beta}$ (1), bähdatee $\boldsymbol{\beta}$ (4).

Tomēr 17 gadījumos parādās arī rakstība ar - $h$-, piem. - ehtees (1) / -ehtee $\beta$ (14), -ahteeß (2), piem., wafahteeß (1), wahrdJenahteeß (1).

\subsection{K. Fīrekera reliǵiskie raksti (1685)}

Fīrekera reliğiskajos darbos tiešo darbības vārdu nenoteiksmē - $h$ - lietots visos 553 gadijumos, tostarp: -aht (126), - eht (218), -iht (300), -oht (122), piem., runnaht (27), dfirdeht (11), darriht (80), kalpoht (8).

Turpretim visas refleksivvo verbu nenoteiksmes formas rakstītas bez $-h-$ pirms atgriezeniskā formanta: -etees (19); -itees (53); -otees (9); - atees (7), piem., behdatees (1), istruhzinatees (1), nośargatees (1). 


\subsection{E. Glika Bībeles tulkojums (1685-1694)}

Bībelē nenoteiksmes galotnēs regulāri izmantota rakstība ar - $h$ - gan tiešo, gan atgriezenisko darbības vārdu formās.

Kopumā aplūkotajās Bībeles grāmatās rakstība ar - $h$ - izmantota 4593 galotnēs, tostarp -eht (1268), piem., dfirdeht, eenihdeht; -iht (1978), piem., atraiśiht, darriht; - oht (517), piem., kalpoht; kā arī-aht (1009), piem., jautaht, kahrdinaht. Tikai 6 gadījumos šajā pozīcījā - $h$ - neparādās, 5 reizes - ar galotni -at: finnat (5), un tikai 1 reizi - ar -et: śpihdet.

Atgriezeniskajiem verbiem nenoteiksmē visos 369 gadījumos reǵistrēta rakstība bez - $h$ - pirms atgriezeniskā formanta, piem., -etees (84), piem., turretees (9); -itees (132); -otees (47), kā arī -atees (106), piem., preezatees (20), śalihdfinatees (2).

4. tabula

Nenoteiksmes galotnes 17. gs. rakstos

\begin{tabular}{|l|c|c|c|c|c|}
\hline \multirow{2}{*}{} & \multicolumn{2}{|c|}{ Bībele } & \multirow{2}{*}{ VLH } & LP1 & kopā \\
\cline { 2 - 3 } & JD & VD & & & \\
\hline -Vt & 711 & 3882 & 748 & 1267 & 6608 \\
\hline -Vhtees & 4 & 1 & - & 6 & 11 \\
\hline -Vtees & 82 & - & - & 17 & 17 \\
\hline kopā & 797 & 4169 & 802 & 1408 & 7167 \\
\hline
\end{tabular}

\subsection{Kopsavilkums}

Apkopojot - $h$ - rakstību darbības vārdu nenoteiksmēs, redzams, ka:

1) visiem autoriem tiešo verbu nenoteiksmes izskaņas rakstītas ar - $h$-;

2) atgriezenisko verbu nenoteiksme lielākoties rakstīta bez $-h$-, tikai Mancelis reizēm lieto arī formas ar - $h$ -

\section{Rezultātu analīze}

Analizētais 17. gs. avotu materiāls ḷauj atbildēt uz vairākiem no pētījuma ievadā izvirzītajiem jautājumiem.

1) Darbības vārdu īstenības izteiksmes dsk. 1. un 2. pers. galotņu rakstībā ir konstatēti varianti - ar un bez - $h$ - aiz patskaņa.

2) Nevienā no tekstiem atšksirība starp tagadnes un pagātnes galotnēm grafiski nav apzīmēta, to var noteikt vienīgi no darbības vārda konteksta. 
3) Pamatojoties uz galotņu rakstības atšķirībām, tekstus var dalìt 2 grupās:

- ar - h-dsk. 2. pers. galotnē -aht-

- 1654. g. Manceḷa Sprediķu grāmata (LP1),

- 1667.-1677. g. Bihnera fragmenti (A),

- 1685. g. Dresel̦a gramatika (GKA),

- 1685. g. Fīrekera teksti Kurzemes rokasgrāmatā (VHL),

- 1685. g. Jaunā Testamenta dalas - Mateja un Marka evaņgéeliji (Mt un Mk);

- bez $-h-$ dsk. 2. pers. galotnē $-a t-$

- 1644. g. Rēhehūzena gramatika (MLL),

- 1685. g. Langija gramatika (L),

- 1685. g. Ādolfija gramatika (EV),

- 1685. g. Jaunais Testaments (JD) (izņemot Mt un Mk),

- 1689. g. Vecā Derība (VD).

4) Starp tekstiem nav atšksirīības tiešo verbu nenoteiksmes formu rakstībā galotnes vienmēr rakstìtas ar $-h-$. Atgriezenisko verbu formās pārsvarā lietota galotne bez $-h-$, tomēr Manceḷa darbā parādās arī izskaņas ar $-h-$.

5) Novērota tendence katram autoram izvēlēties vienu konkrētu dsk. 2. pers. galotnes rakstību - ar vai bez $-h-$. Vienīgi Glika Bỉbeles teksts nav uzskatāms par veselumu. Mt un Mk sekots Mancel̦a un Kurzemes rokasgrāmatā lietotājam paraugam, bet Jṇ un citās JD, kā arī VD grāmatās Ādolfija gramatikai. Lk tekstā redzams paralēls abu sistēmu lietojums.

6) Veiktais pētījums nedod skaidru atbildi par grafēmas $-h$ - funkcijām. Kā potenciāls patskaņa garuma apzīmètājs - $h$ - apskatìtajos tekstos lietots:

- vārda saknē, piem., atgahdinahs (1);

- gala zilbē, piemēram, nenoteiksmē, nākotnes formās, piem., atlaidihs (1), atbildehs (4), kā arī citur, piem., siev. dz. lietvārdu, numerāḷu un vietniekvārdu dsk. datīva un instrumentāla formās, piem., BEt no tahm garrigahm Dahwanahm/ Brahlil/ ne gribbu es jums ślehpt. (JT 1Kor 12:1);

- atgriezenisko $\bar{a}$-celmu darbības vārdu 3. pers. formām raksturīgā galotne -ahs tiek lietota arī citu celmu, tostarp o-celmu, formās gan tagadnē, gan pagātnē, piem., Jpeefchahs un fpeedahs (VD), apprezzahs un apprezejahs (JD).

Turpretim garums parasti nav apzīmēts:

- $\quad$ pirmspēdējā zilbē, tostarp piedēkḷ̆os, piem., atmaksajeet (1), atmakśajaht (1), guhftija (1), kā arī refleksīvo verbu personu un nenoteiksmes galotnēs;

- 3. konjugācijas $\bar{a}$-celma verbu ar galotni -ìt, -ināt tagadnes dsk. 1. un 2. pers. formās, kuras mūsdienās raksta: 1. -ām, 2. -āt, piem., las-ām, las-āt, un šo darbības vārdu attiecīgās pagātnes formās (LVG 519). Viens no garuma neapzīmēěanas iemesliem var būt analog̣ijas procesi 
latviešu valodas izloksnēs, kur $\bar{a}$-celma formas tagadnes dsk. 1. un 2. pers. sakritušas ar attiecīgām $o$-celma formām, un tās izmantotas bez garuma izskaņā. Fonētisko galotnes garuma zudumu Endzelīns (1951: 832-833) konstatējis, piem., Dunalkā un Dobelē. Par otru iemeslu var tikt uzskatīta sekošana citu autoru ieviestajai rakstu tradīcijai;

- ar - $h$ - nav atzīmēta sagaidāmā opozīcija starp verbu tagadnes (parasti ar īsu patskani) un pagātnes (ar garu patskani) galotnēm.

Konstatētās atškịirības formu rakstībā JD daḷās vedina uz domām par Glika rakstības sistēmas attīistību. Ja Bībeles tulkošanas procesa secība sakrita ar Bībeles grāmatu izdošanas secību, varētu domāt, ka konstatētās galotņu rakstības izmaiņas liecina par pārejas procesu. Iesākdams ar iepriekšējo autoru tradīciju, Gliks pakāpeniski pāriet uz jaunu, Ādolfija gramatikā balstītu, rakstības sistēmu.

No vienas puses, šis atzinums varētu būt kārtējais apstiprinājums hipotēzei par Kurzemes mācītāju konferences ietekmi uz Bībeles tulkošanas gaitu (sk. Straubergs 1943: 199; Karulis 1989: 17-18).

No otras puses, tas liecina par sava veida pārmantojamību. Gliks savā darbā ir balstīijies vai pat izmantojis citu autoru tulkojumus. Manceḷa darbos izmantotais princips - dsk. 2. pers. lietot galotni -aht - atkārtots Fīrekera Bībeles fragmentu tulkojumā, kā arī Glika JT Mt un Mk evaņgēèlijos.

Šì pārmantojamība skaidri redzama arī tendencē Mt un Mk evaņgéēlijos pagātnes 3. pers. formās lietot pārsvarā galotni -e (Wiśnioch 2015: 119-141), līdzīgi kā Manceḷa darbos.

Tas sakrīt arī ar E. Lāmes secinājumiem par log̣iskās rakstības principiem tie plaši izmantoti Mancel̦a darbos un pēc tam atkārtoti Glika Mt un Mk, bet ne citās Bībeles grāmatās.

Attiecībā uz - $h$ - lietojumu 17. gs. rakstītajos tekstos jāsecina, ka tas nevar būt viennozīmīgi uzskatāms par garuma apzīmētāju. Analīzes rezultāti drīzāk norāda uz tendenci viena tekstā ietvaros lietot vienu rakstības sistēmu.

Šai tendencei varētu būt 2 iemesli:

1) maksimāli vienkāršot un sistematizēt rakstību. Tā rezultātā tekstos latviešu valodas morfolog̣ija tiek pakḷauta mehāniskiem rakstības principiem;

2) precīzi sekot vienai izvēlētai rakstības tradīcijai, vai - kā Glika gadījumā - vienlaikus pat 2 rakstu tradīcijām viena darba ietvaros.

\section{Secinājumi}

Apkopojot pētìjuma rezultātus un to analīzi, var iezīmēt 17 gs. tekstiem raksturīgas kopīgas parādības:

- izvēēètais darbības vārdu īstenības izteiksmes dsk. 1. un 2. pers. galotnes variants lietots gan tagadnē, gan pagātnē; 
- dsk. 1 pers. galotne abos laikos rakstìta bez - $h$-;

- atgriezenisko verbu dsk. 1 un 2. pers. galotne rakstīta bez $-h-$;

- nenoteiksmes formas tiešajiem verbiem rakstītas ar - $h$-, bet atgriezeniskajiem - bez tā;

Bībeles tulkojumā novērotā pāreja no Manceḷa lietotā $-h$ - dsk. 2. pers. galotnēs pie Ādolfija gramatikā noteiktās rakstības bez - $h$ - nav uzskatāma par pāreju uz „pareizāku“ un latviešu runātai valodai tuvāku rakstības variantu, bet par pāreju uz Ādolfija autoritātē balstītu rakstības sistēmu. Šajā gadījumā galotņu -aht un -at lietojums uzskatāms par vēl vienu log̣iskās rakstības paņēmienu, kas lietots ar vēlmi sakārtot un sistematizēt latviešu rakstu valodu.

\section{Avoti}

\begin{tabular}{|c|c|}
\hline$=$ & $\begin{array}{l}\text { ramatiskie ieraksti mācītāia Bihnera albumā. Citēts no: Fennell, Trevor G. Seven- } \\
\text { enth-Century Latvian Grammatical Fragments. Melbourne: Latvian Tertiary } \\
\text { ommittee, } 1982 .\end{array}$ \\
\hline$V=$ & $\begin{array}{l}\text { rfter Verfuch Einer kurtz=verfaffeten Anleitung Zur Lettifchen Sprache.. von Henrico } \\
\text { dolphi.. Mitau.. George Radetzky/1685. }\end{array}$ \\
\hline $\mathrm{rA}$ & $\begin{array}{l}\text { antz kurtze Anleitung zur Lettifchen Sprache.. Georgio Drefzell.. Riga Jn Verlegung } \\
\text { eorg Matth. Nöllers Jm Jahr Chrifti } 1685 .\end{array}$ \\
\hline$=$ & $\begin{array}{l}\text { as Jauns Teftaments Muhśu Kunga Jefus Kriftus.. Riga.. Johann Georg Wilcken.. } \\
\text { I DC LXXXV. }\end{array}$ \\
\hline$=$ & $\begin{array}{l}\text { ttifch=Deutfches Lexicon.. Sampt einer kurtzen Grammatica.. von Johanne Langio.., } \\
\text { itēts no: Fennell, Trevor G. The Grammatical Appendix to Johannes Langius' } \\
\text { atvian-German Lexicon. Melbourne: Latvian Tertiary Committee, } 1987 .\end{array}$ \\
\hline $1=$ & $\begin{array}{l}\text { urch Georgium Mancelium Semgallum.. Erfter } \\
\text { 4. }\end{array}$ \\
\hline I & $\begin{array}{l}n \text { facilis \& certa, monftrata à Joanne Georgo } \\
\text { lero Typothetâ Rigenfi.. Anno MDCXLIV. Citēts } \\
\text { vian Grammar: J.G. Rehehusen's „Manuductio } \\
\text { etext with annotated translation \& commentary. } \\
\text { ttee, } 1982 .\end{array}$ \\
\hline $\mathrm{VD}=$ & 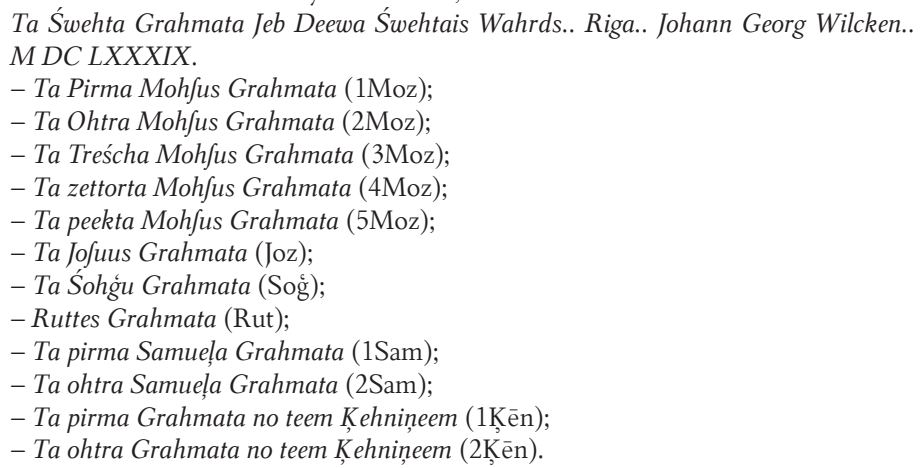 \\
\hline & Vermehretes Lettifches Hand=Buch.. außgefertiget von $\mathrm{He}$ \\
\hline
\end{tabular}


VLH Cat $=$ Der kleine Catechifmus/ D. Martini Lutheri.. Mitau.. George Radetzky/ 1685.

VLH Sal = Die Sprüche Salomonis.. Mitau.. George Radetzky/ 1685.

VLH Syr $=$ Das Hauß=, Zucht= vnd Lehr=Buch Jefus Syrachs.. Mitau.. George Radetzky/ 1685.

\section{Literatūra}

Bērzin̨š, Ludis. 1935.

Bērziņš̌, Ludis. 1939.

Endzelīns, Jānis. 1951.

Fennell, Trevor G. 1982.

Fennell, Trevor G. 1984.

Fennell, Trevor G. 1987.

Grabis, Rūdolfs. 1955.

Grīsle, Rasma. 1959.

Karulis, Konstantīns. 1989.

Lāme, Emīlija. 1933.

$\mathrm{LVG}=$

Reiters, Jānis. 1975.

Straubergs, Jānis. 1943.

Šmits, Pēteris. 1908.

Wiśnioch, Jolanta. 2015.
Ernsts Gliks, Darba mūžs un mūža darbs. Rīga: Latvijas ev.-lut. baznīcas virsvalde, Spst. „Izdevējs“.

Ernsts Gliks tulkotāja darbā. Izglìtības Ministrijas Mēnešraksts, 2, 149-161.

Latviešu valodas gramatika. Rīga: Latvijas Valsts izdevniecība.

The first Latvian grammar: J.G. Rehehusen's „Manuductio ad linguam lettonicam ...": a facsimile text with annotated translation \& commentary. Melbourne: Latvian Tertiary Committee.

Georg Dreszell's Gantz kurtze Anleitung Zur Lettischen Sprache: text, translation, commentary, concordance. Melbourne: Latvian Tertiary Committee.

The grammatical appendix to Johannes Langius' Latvian-German lexicon. Melbourne: Latvian Tertiary Committee.

Pārskats par 17. gadsimta latviešu valodas gramatikām. Valodas un literatūras institūta raksti, V, 205-266.

Rēhehūzena gramatika un pret to vērstais Einhorna raksts. Rakstu krājums veltījums akadēmiķim profesoram Dr. Jānim Endzelīnam vina 85 dzīves un 65 darba gadu atcerei. Rīga: Latvijas PSR Zinātņu akadēmijas izdevniecība, 479-526.

Bībeles pirmais izdevums latviešu valodā. 1685-1694. Rīga: Raiņa literatūras un mākslas vēstures muzejs.

Log̊iskais princips Glüka rakstībā. Filolog̣ijas materiāli. Rīga: Ramave, 104-110.

Latviešu valodas gramatika. Rīga: LU Latviešu valodas institūts, 2013.

Tulkojuma paraugs. 1675. gadā Rīgā iznākušo latviešu Bībeles tekstu faksimiliespiedums. Ar B. Jēgera apceri. Daugava.

Kā noritēja Bībeles tulkošanas darbs. Izglìtības Mēnešraksts, 9, 197-200.

Glüka Bībeles valoda. Rīga: Rīgas Latviešu Biedrības Zinību Komisijas Rakstu kräjums, XIV, 21-100.

Darbības vārdu pagātnes formu distribūcijas likumi Glika Bībeles tulkojumā. Baltu filoloǵija, XXIV (2), 119-141.

Jolanta Wiśnioch

Baltu valodniecības katedra

Humanitāro zinātnu fakultāte

Latvijas Universitäte

Visvalža iela 4a, Rīga, LV-1050, Latvija

jolawisnioch@gmail.com 


\title{
SUMMARY
}

\section{The Use of First and Second Person Plural (Present and Past Tense) Endings -am/-at and -ahm/-aht

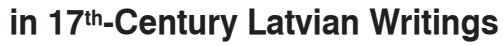

\author{
Jolanta WIŚNIOCH
}

In the modern Latvian literary language the orthography goes hand in hand with grammar and there are two separate endings of the indicative plural forms of the first and second person - short -am, -at (with the exception of the $\bar{a}$-stem verb forms in -ìt, -ina $\bar{a} t$ ) in the present tense - and long $-\bar{a} m,-\bar{a} t$ for the past tense. However in the history of the Latvian written language it hasn't always been like this. The analysis of the two mentioned endings in Latvian texts of the $17^{\text {th }}$ century shows, that there are two different ways to mark the ending of the plural forms of the second person - with and without $-h$ - in the ending.

Accordingly, the writings of the $17^{\text {th }}$ century can be divided into two groups. On the one hand the writings of G. Mancelius, M. Büchner, G. Dreszell and H. Adolphi (Vermehretes Lettifches Hand=Buch, 1685), where the ending -aht prevails and on the other hand the works of J. G. Rehehusen, J. Langius, and those of E. Glück and H. Adolphi (Erfter Verfuch Einer kurtz=verfaffeten Anleitung Zur Lettifchen Sprache, 1685) - with the ending -at.

In all the texts, except Glück's Bible, one particular variant of the ending -at or -aht serves as the plural second person ending indicator in both tenses - present and past.

In the Bible two systems are used - the ending - aht in the gospels of Matthew and Mark and the ending -at in John and the other books. The Gospel of Luke shows both writing systems at the same time.

All the authors use $-h$ - as an indicator of the long syllable at the end of infinitive forms, but they don't use it in the case of reflexive verbs - neither in the infinitive, nor in the plural forms of the second person.

This provides further evidence that Glück followed or used the works of his predecessors and, perhaps, was influenced by the "modern" writing tradition introduced in Adolphi's grammar. 